\title{
A CASE STUDY ON CHARACTERISTICS OF SOLID WASTE \& LEACHATE TREATMENT OF OKHLA LANDFILL-NEW DELHI
}

\author{
Sunita Bansal ${ }^{1}$, Srijit Biswas ${ }^{2}$ \\ ${ }^{1}$ Associate Professor, Deptt. of Civil Engg., FET, Manav Rachna International University, Faridabad, India \\ ${ }^{2}$ Professor, Dept. of Civil Engg, FET, Manav Rachna International University, Faridabad, India
}

\begin{abstract}
Delhi is the most densely populated and urbanized city of India. The annual growth rate in population during the last decade was almost double the national average. Delhi is also a commercial hub, providing employment opportunities and accelerating the pace of urbanization, resulting in a corresponding increase in municipal solid waste (MSW) generation. Presently Delhi generating about 6500 tonnes/day of MSW out of which only 70-75\% wastes are able to collect by the MSW management authority and rest amount of wastes are not possible to collect for the habit of people to thrown the wastes in empty places. At present three main landfill sites of Delhi are Bhalaswa at north Delhi, Ghazipur at east Delhi, and Okhla at south Delhi. But not a single landfill are sanitary landfill rather wastes are dumping crudely as a heap of wastes in open landfill. As a result the leachate generated due to percolation of rain water and squeezing of wastes itself posing a great threat in the surrounding soil structure of the landfill. Around the periphery of landfill, soils gets highly contaminated and toxic and degraded it's essential nutrients [4,6]. In this paper a case study on characteristics of solid wastes of Okhla landfill and performance of it's leachate treatment is carried out for future planning and proper management of soil structure around the periphery of landfill site.
\end{abstract}

Keywords: BOD, COD, E-coli, leachate, solid waste, TDS, etc ****.

\section{INTRODUCTION}

Solid wastes are generated due to human as well as industrial activities and discarded directly or indirectly after it's full utilisation. Any wastes other than human excreta, urine \& waste water is called solid wastes. The process of collection, transportation, treatment, and disposal can be grouped under solid waste management. Most of the landfill are being used only for ultimate disposal of municipal waste without any environmental protection $[1,3]$. When moisture exceeds the field capacity of the waste matrix as a result of percolation of rain water it squeezing the waste itself and form leachate. It contains a wide variety of hazardous chemicals and when transmitted around it's soil structure it degrades the quality of original soil [2]. To minimize these problems a composting plant is working in Okhla landfill and now it is the biggest solid waste management plant working in Delhi. After collection of total wastes, all the inorganic materials are discarded to landfill directly and only the biodegradable wastes are shifted to composting plant for generation of electricity. The waste is burnt sequence wise and an ash is collected to dump at landfill. Out of total quantity of wastes, only $20 \%$ of it are possible to transfer to composting plant daily. Thus major quantity of wastes is ultimately dumping into the landfill crudely. But Okhla landfill is not a sanitary landfill rather $100 \%$ crude dumping type landfill. Thus leachate produced from the wastes percolate towards downward direction as well as moves towards horizontally too openly.
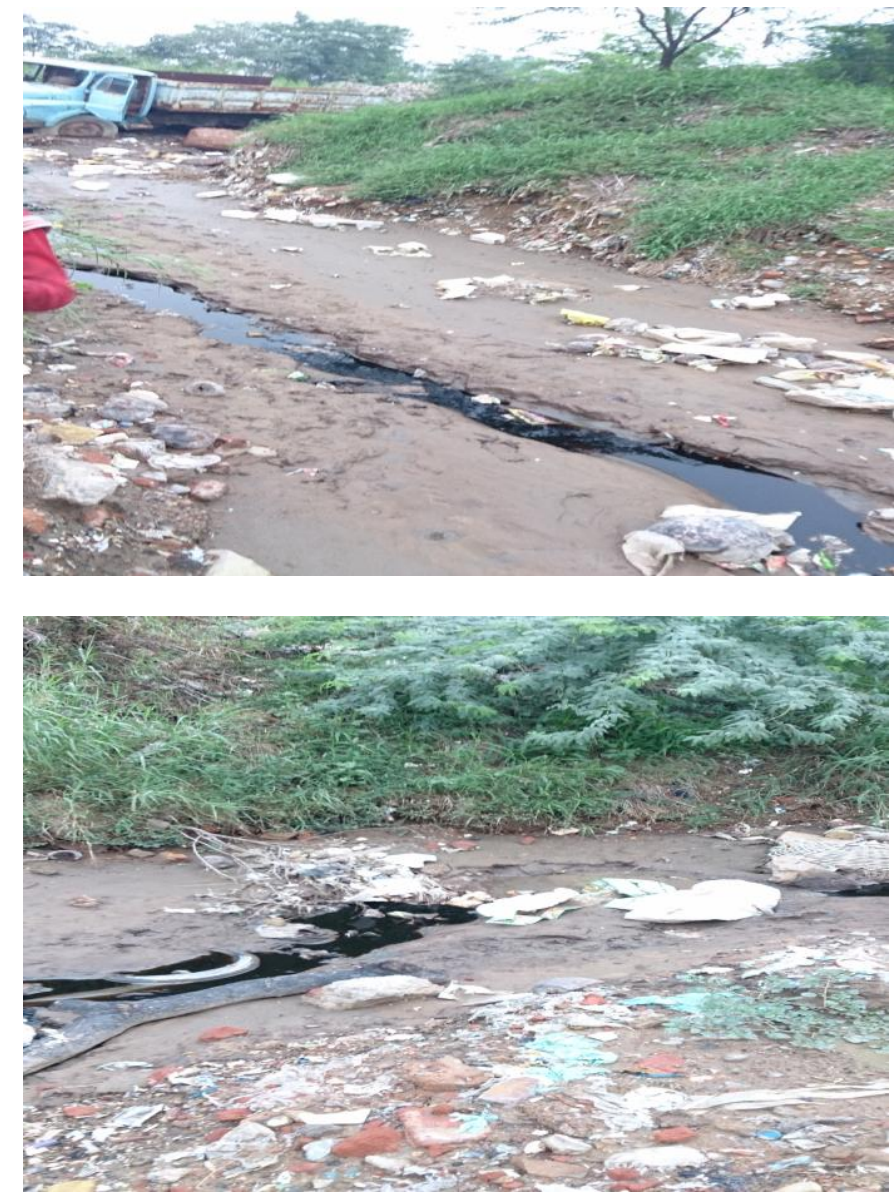

Fig 1: Open leachate movement around the periphery of Okhla landfill 
At present there is no facility available to MSW management authority of Delhi to give proper protection of leachate flow or have any technology for it's treatment before coming in touch with open soil. Thus to protect the soil from anticipated toxicity of leachate, a vigorous case study on the characteristics of solid wastes and it's leachate is very essential. In this paper, light is beamed on the severity of degradation of the existing soil structure around the periphery of Okhla landfill site and analyze the performance of leachate treatment by different technological options [5].

\section{METHODOLOGY}

The proposed methodology includes two main phases, one is the analysis of solid wastes characteristics and second is leachate characteristics with it's treatment by physicochemical process. In below both phases of study are briefly discussed for better understanding the present scenario of soil degradation of Okhla landfill.

\subsection{Analysis of Solid Waste Characteristics}

A solid waste samples represent the average quality of waste with average amount of it's different constituents of the waste collected from all sources under it's jurisdiction. To collect all these wastes from different locations, nos. of vehicles are working daily under Delhi MSW management authority. In this phase of case study approximate $30-40 \mathrm{~kg}$ of waste is collected from a vehicle of each location as a source of waste sample of that locality of Delhi and then mixed all the samples thoroughly. For simplicity in assessment the average percentages of each component of wastes, $100 \mathrm{~kg}$ of mixed wastes are taken for segregation. All segregated components are then measured individually by ordinary owing machine available in the local market and all the data are noted for further course of analysis.

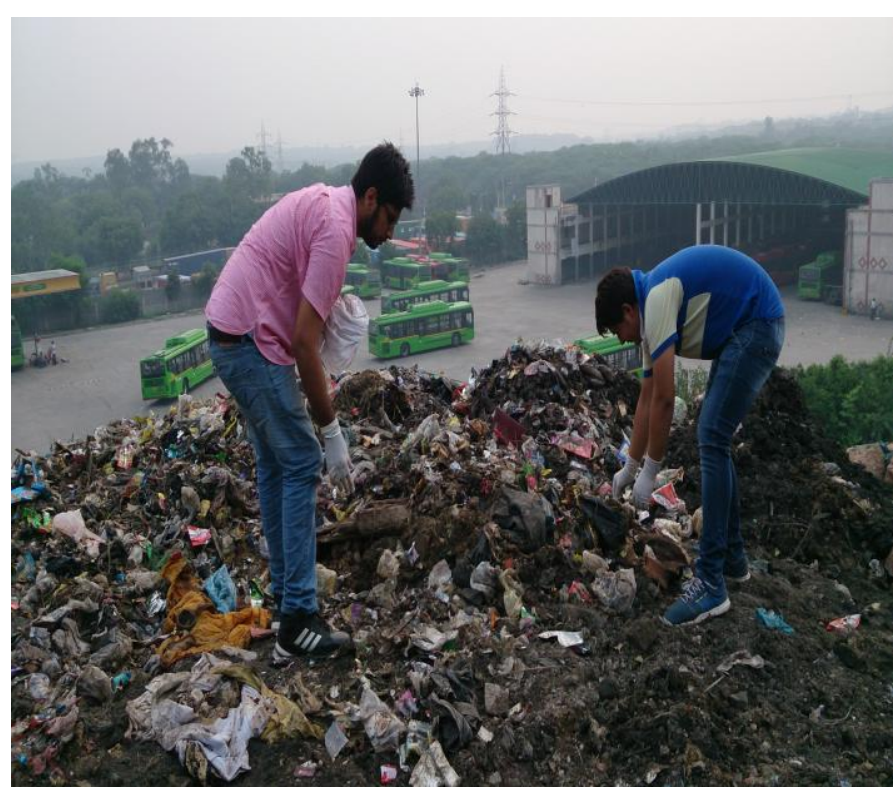

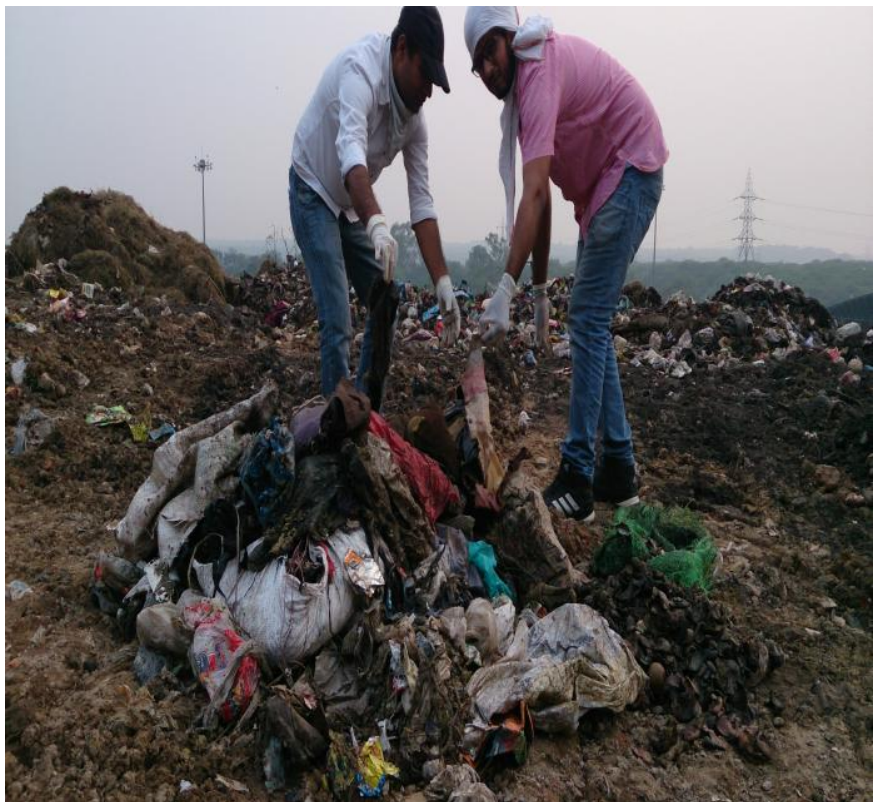

Fig-2: Segregation of solid wastes collected from different vehicles

\subsection{Analysis and Treatment of Leachate}

In the second phase, characteristics of leachate and it's treatment are studied considering two environmental conditions i.e without rainfall condition and with rainfall condition. In both cases of conditions two different samples are collected, one is directly from landfill site and another s is generated in the laboratory.

\subsubsection{Sample Collection from Landfill Site}

At present there is no systematic mechanism available for leachate collection in Okhla landfill rather it is coming drop by drop from bottom of the heap. For the sample of without rainfall condition, initially ten samples are collected separately from ten different locations around the periphery of landfill by a 2" PVC pipe channel and then mixed all these samples into a big jar. For the case of with rainfall condition, sample is collected from the landfill just after the day of heavy rainfall in the landfill site. 


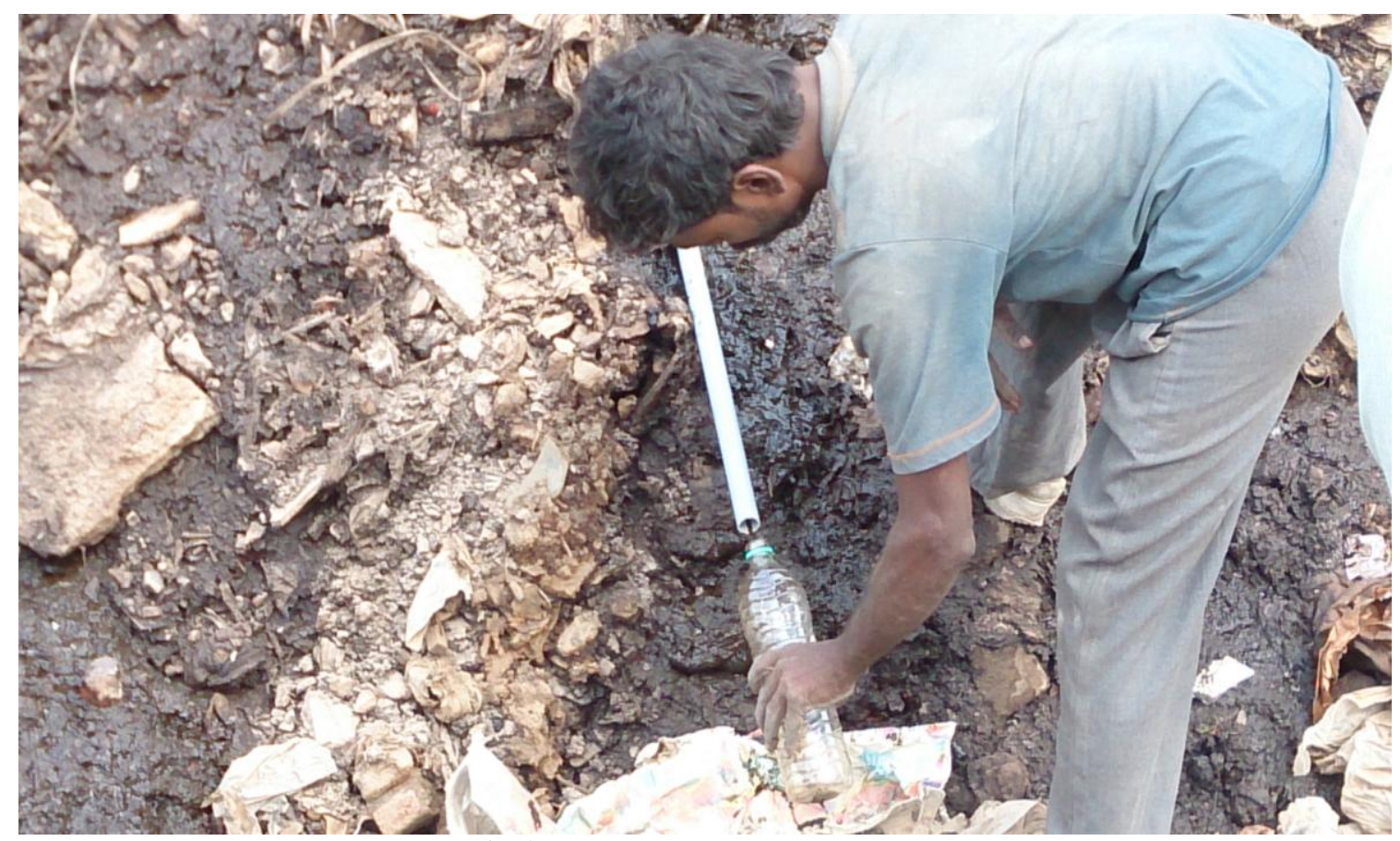

Fig-3 : Process of leachate collection

\subsubsection{Sample Generated in the Laboratory}

From the mixed wastes as discussed in section-2.1, roughly $100 \mathrm{~kg}$ of solid wastes is collected for generation of leachate samples in the laboratory. Out of this $100 \mathrm{~kg}, 50 \%$ of solid wastes are kept in a closed container for formation of leachate by anaerobic decomposition and rest $50 \%$ of wastes are kept in an open container with a provision of artificial rainfall from top and lower portion is for storage of leachate.

\subsubsection{Leachate Treatment}

In this section the leachate treatment has been studied by two different methods, one is physico-chemical treatment using lime \& alum and second is physico-chemical with anaerobic biological treatment. In biological treatment samples are dilute by water in $1: 1$ ratio before adding of chemicals. Dosing applied in physico-chemical treatment are $100 \mathrm{mg} / 1,150 \mathrm{mg} / 1,200 \mathrm{mg} / 1,250 \mathrm{mg} / 1$, and $300 \mathrm{mg} / \mathrm{l}$ followed by 1 -minute rapid mixing and 5-minutes slow mixing time with detention period of 2-hours for each. In physico-chemical with anaerobic biological treatment, dosing are applied same with same rapid mixing and slow mixing time but detention time are kept as 5-days instead of $2 \mathrm{hrs}$. The flow diagram of physico-chemical with anaerobic biological treatment is shown below:

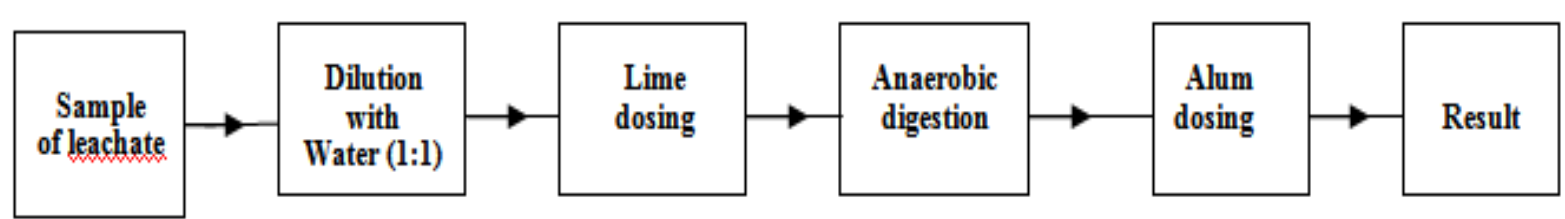

For the simplicity in laboratory experiments, following parameters are considered for all leachate samples: $\mathrm{pH}, \mathrm{BOD}_{3}\left(27^{0} \mathrm{C}\right)$, COD, TKN, TS, SS, DS, E Coli.

\section{CASE STUDY}

Okhla landfill is purely a open and crude dumping landfill and has no barricade around it's periphery to protect the leachates movement. Thus collection of leachate sample is not a great problem from the bottom of it's heap. The first phase of the case study is conducted continuously for eight days. Every day, about 30-40 kg of wastes are collected from different 15 vehicles as a source of wastes of 15 different locations of New Delhi. There after $100 \mathrm{~kg}$ of mixed wastes from these 15 samples are taken into consideration for analysis daily. All these analysis data are tabulated in table- 1 for further calculation of average typical composition of solid waste of landfill in table-2. A graphical analysis (Graph-1) is also presented to compare the variation of each component of wastes of Okhla landfill. 
Table-1: Analysis the Composition of Solid Wastes of Okhla landfill

\begin{tabular}{|c|c|c|c|c|c|c|c|c|c|}
\hline \multirow{2}{*}{\begin{tabular}{l}
\multicolumn{2}{c}{ Compositi } \\
on of \\
waste
\end{tabular}} & \multicolumn{9}{|c|}{$\%$ by mass of weight } \\
\hline & $\begin{array}{l}\text { On } \\
10.09 .1 \\
4 \\
\end{array}$ & $\begin{array}{l}\text { On } \\
12.09 .1 \\
4 \\
\end{array}$ & $\begin{array}{l}\text { On } \\
19.09 .14\end{array}$ & $\begin{array}{l}\text { On } \\
24.09 .1 \\
4 \\
\end{array}$ & $\begin{array}{l}\text { On } \\
29.09 .14 \\
\end{array}$ & $\begin{array}{l}\text { On } \\
02.10 .1 \\
4 \\
\end{array}$ & $\begin{array}{l}\text { On } \\
04.10 .1 \\
4 \\
\end{array}$ & $\begin{array}{l}\text { On } \\
12.10 .1 \\
4 \\
\end{array}$ & Average \\
\hline $\begin{array}{l}\text { Food } \\
\text { waste }\end{array}$ & 35.30 & 27.60 & 38.15 & 12.50 & 19.75 & 25.25 & 28.65 & 16.85 & 25.506 \\
\hline Paper & 12.35 & 11.20 & 8.40 & 10.50 & 6.85 & 7.45 & 9.25 & 10.35 & 9.544 \\
\hline Plastic & 7.00 & 10.00 & 6.25 & 8.55 & 11.25 & 5.50 & 6.25 & 3.55 & 7.294 \\
\hline $\begin{array}{l}\text { Garden } \\
\text { wastes }\end{array}$ & 9.50 & 7.20 & 11.50 & 9.00 & 15.15 & 10.50 & 12.40 & 19.10 & 11.794 \\
\hline Wood & 1.20 & 0.60 & 2.10 & 0.50 & 0.35 & 1.25 & 0.75 & 0.65 & 0.925 \\
\hline Rubber & 0.25 & 0.10 & 1.40 & 0.60 & 0.15 & 1.35 & 0.15 & 1.15 & 0.644 \\
\hline Leather & 0.25 & 0.15 & 0.50 & 0.55 & 1.35 & 0.65 & 0.85 & 0.60 & 0.613 \\
\hline Glass & 0.50 & 0.65 & 2.25 & 1.45 & 0.55 & 0.85 & 3.25 & 2.10 & 1.450 \\
\hline Tin cans & 3.45 & 2.20 & 1.50 & 6.25 & 2.30 & 4.50 & 1.75 & 2.50 & 3.056 \\
\hline $\begin{array}{l}\text { Demolitio } \\
\text { n wastes }\end{array}$ & 11.70 & 24.30 & 6.10 & 16.30 & 23.40 & 27.45 & 15.50 & 16.00 & 17.594 \\
\hline Textile & 2.00 & 1.90 & 0.75 & 2.80 & 1.75 & 1.20 & 5.35 & 1.40 & 2.144 \\
\hline $\begin{array}{l}\text { Ferrous } \\
\text { materials }\end{array}$ & 1.20 & 2.00 & 0.50 & 1.50 & 2.80 & 0.65 & 1.30 & 1.90 & 1.481 \\
\hline $\begin{array}{l}\text { Special } \\
\text { waste* }\end{array}$ & 14.50 & 11.70 & 19.50 & 28.75 & 12.45 & 13.25 & 10.90 & 23.35 & 16.800 \\
\hline $\begin{array}{l}\text { Other } \\
\text { misc. }\end{array}$ & 0.80 & 0.40 & 1.10 & 0.75 & 1.90 & 0.15 & 3.65 & 0.50 & 1.16 \\
\hline Total & 100 & 100 & 100 & 100 & 100 & 100 & 100 & 100 & 100.00 \\
\hline
\end{tabular}

* Wastes from street sweeping, road side litters, catch basin debris, dead animals etc.

Table-2: Average Typical Composition of Solid Waste of Okhla Landfill

\begin{tabular}{|c|c|c|c|}
\hline Composition of Waste & $\begin{array}{l}\text { Average } \% \text { by } \\
\text { mass of weight }\end{array}$ & & \multirow{16}{*}{$\begin{array}{l}\text { Total Biodegradable } \\
\text { Wastes = 58.464 \% } \\
\text { Total Non- } \\
\begin{array}{l}\text { Biodegradable Wastes = } \\
\text { 41.536 \% }\end{array}\end{array}$} \\
\hline Food wastes & 25.506 & Biodegradable & \\
\hline Paper & 9.544 & Biodegradable & \\
\hline Plastic & 7.294 & Non-Biodegradable & \\
\hline Garden Trimmining & 11.794 & Biodegradable & \\
\hline Wood & 0.925 & Biodegradable & \\
\hline Rubber & 0.644 & Biodegradable & \\
\hline Leather & 0.613 & Biodegradable & \\
\hline Glass & 1.450 & Non-Biodegradable & \\
\hline Tin cans & 3.056 & Non-Biodegradable & \\
\hline Demolition wastes & $\mathbf{1 7 . 5 9 4}$ & Non-Biodegradable & \\
\hline Textile & 2.144 & Biodegradable & \\
\hline Ferrous materials & 1.481 & Non-Biodegradable & \\
\hline Special waste* & 16.800 & Non-Biodegradable & \\
\hline Other misc. & 1.16 & Non-Biodegradable & \\
\hline Total & 100.00 & & \\
\hline
\end{tabular}




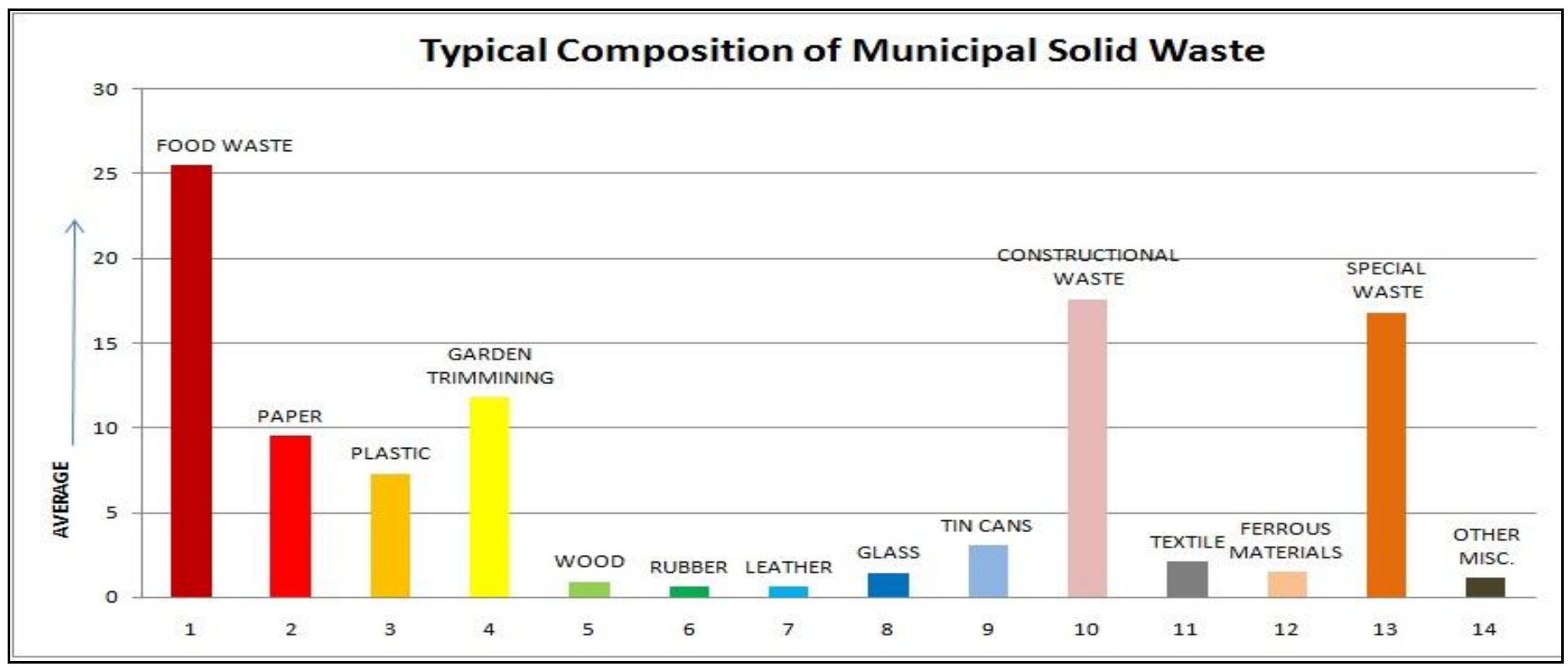

Graph-1: Comparison of all Components of Wastes of Okhla Landfill

The second phase is studied for the analysis leachate characteristics and it's treatment for the following four catagories of samples:

$>$ Leachate sample directly from the landfill site without rainfall condition

$>\quad$ Leachate sample collected directly from the landfill site with rainfall condition

$>$ Leachate sample generated in laboratory without rainfall condition

> Leachate sample generated in laboratory with rainfall condition

To generate the leachate sample in laboratory with rainfall condition, the artificial rainfall are maintained as under:

\begin{tabular}{|l|l|}
\hline Date & Rainfall in $\mathbf{~ m m} / \mathbf{h r}$. \\
\hline $12-10.2014$ & 35 \\
\hline $28-10-2014$ & 20 \\
\hline $02-11-2014$ & 10 \\
\hline $14-11-2014$ & 12 \\
\hline $22-11-2014$ & 8 \\
\hline
\end{tabular}

Now the job is to do the laboratory test results of all category of leachate samples along with it's treatment followed by two different technology.

In the first case of job, all laboratory test results of leachate samples collected directly from landfill site (without rainfall condition) are tabulated below :

Table-3: Characteristics of raw leachate

\begin{tabular}{|l|ll|}
\hline Parameters & Value & \\
\hline $\mathrm{pH}$ & 7.47 & $\mathrm{mg} / \mathrm{l}$ \\
\hline $\mathrm{BOD}_{3}\left(27^{\circ} \mathrm{C}\right)$ & 6500 & $\mathrm{mg} / \mathrm{l}$ \\
\hline $\mathrm{COD}$ & 17300 & $\mathrm{mg} / \mathrm{l}$ \\
\hline
\end{tabular}

\begin{tabular}{|l|l|}
\hline \multicolumn{2}{|l|}{$\frac{\mathrm{BOD}_{3}}{C O D}$ ratio $=0.375$} \\
\hline TKN & $180 \mathrm{mg} / \mathrm{l}$ \\
\hline TS & $19220 \mathrm{mg} / \mathrm{l}$ \\
\hline $\mathrm{SS}$ & $57 \quad \mathrm{mg} / \mathrm{l}$ \\
\hline DS & $19,163 \mathrm{mg} / \mathrm{l}$ \\
\hline Total Coliform (E-coli) & $3.6 \times 10^{5} / 100 \mathrm{ml}$ \\
\hline
\end{tabular}

Table-4: COD-Removal after Alum Treatment

\begin{tabular}{|l|l|l|l|}
\hline $\begin{array}{l}\text { Alum } \\
\text { dosing } \\
\text { mg/l }\end{array}$ & $\mathbf{p H}$ & $\begin{array}{l}\text { COD } \\
\mathbf{m g} / \mathbf{l}\end{array}$ & $\begin{array}{l}\text { \% } \\
\text { removal }\end{array}$ \\
\hline 100 & 7.41 & 16,200 & 6.36 \\
\hline 200 & 7.38 & 15,500 & 10.40 \\
\hline 250 & 7.35 & 15100 & 12.72 \\
\hline 300 & 7.33 & 14600 & 15.61 \\
\hline 350 & 7.31 & 13800 & 20.23 \\
\hline
\end{tabular}

Table-5: COD-Removal after Lime Treatment

\begin{tabular}{|l|l|l|l|}
\hline $\begin{array}{l}\text { Lime } \\
\text { dosing mg/l }\end{array}$ & $\mathbf{p H}$ & COD mg/l & \% removal \\
\hline 100 & 7.47 & 16900 & 2.31 \\
\hline 200 & 7.58 & 16300 & 5.78 \\
\hline 250 & 7.66 & 15800 & 8.67 \\
\hline 300 & 7.79 & 15200 & 12.14 \\
\hline 350 & 7.83 & 14800 & 14.45 \\
\hline
\end{tabular}

Table-6: COD-Removal after Lime - Alum Treatment

\begin{tabular}{|l|l|l|l|l|}
\hline $\begin{array}{l}\text { Lime } \\
\text { dosing } \\
\text { mg/l }\end{array}$ & $\begin{array}{l}\text { Alum - } \\
\text { dosing } \\
\text { mg/l }\end{array}$ & $\mathbf{p H}$ & $\begin{array}{l}\text { COD } \\
\mathbf{m g} / \mathbf{l}\end{array}$ & $\begin{array}{l}\text { \% } \\
\text { removal }\end{array}$ \\
\hline 100 & 100 & 7.43 & 15,100 & 12.72 \\
\hline 200 & 200 & 7.49 & 14,700 & 15.03 \\
\hline 250 & 250 & 7.52 & 13900 & 19.65 \\
\hline 300 & 300 & 7.56 & 13200 & 23.70 \\
\hline 350 & 350 & 7.58 & 12800 & 26.01 \\
\hline
\end{tabular}


Table-7: COD-Removal after Lime - Alum with Biological Treatment

\begin{tabular}{|l|l|l|l|l|}
\hline $\begin{array}{l}\text { Lime } \\
\text { dosing } \\
\mathbf{m g} / \mathbf{l}\end{array}$ & $\begin{array}{l}\text { Alum } \\
\text { dosing } \\
\mathbf{m g} / \mathbf{l}\end{array}$ & $\mathbf{p H}$ & $\begin{array}{l}\text { COD } \\
\mathbf{m g} / \mathbf{l}\end{array}$ & $\begin{array}{l}\text { \% } \\
\text { removal }\end{array}$ \\
\hline 100 & 100 & 7.43 & 12,300 & 28.90 \\
\hline 200 & 200 & 7.49 & 11,900 & 31.21 \\
\hline 250 & 250 & 7.52 & 11400 & 34.10 \\
\hline 300 & 300 & 7.56 & 10800 & 37.57 \\
\hline 350 & 350 & 7.58 & 10600 & 38.73 \\
\hline
\end{tabular}

As a second case of job, laboratory test result of leachate sample generated in laboratory (without rainfall condition) is tabulated below:

Table-8 : Characteristics for raw leachates

\begin{tabular}{|c|c|c|}
\hline Parameters & Valu & \\
\hline $\mathrm{pH}$ & 8.30 & $\mathrm{mg} / \mathrm{l}$ \\
\hline $\mathrm{BOD}_{3}\left(27^{0} \mathrm{C}\right)$ & 1135 & $\mathrm{mg} / \mathrm{l}$ \\
\hline COD & 4432 & $\mathrm{mg} / \mathrm{l}$ \\
\hline \multicolumn{3}{|c|}{$\frac{B O D_{3}}{C O D}$ ratio $=0.256$} \\
\hline TKN & 26 & $\mathrm{mg} / \mathrm{l}$ \\
\hline $\mathrm{TS}$ & 2535 & $\mathrm{mg} / \mathrm{l}$ \\
\hline $\mathrm{SS}$ & & $\mathrm{mg} / \mathrm{l}$ \\
\hline DS & 2463 & $\mathrm{mg} / \mathrm{l}$ \\
\hline E-coli & $3.6 \mathrm{x}$ & $5 / 100 \mathrm{ml}$ \\
\hline
\end{tabular}

In the third case of job, all laboratory test results of leachate samples collected directly from landfill site (with rainfall condition) are tabulated below :

Table-9: Characteristics for raw leachates

\begin{tabular}{|c|c|}
\hline Parameters & Value \\
\hline $\mathrm{pH}$ & $7.48 \quad \mathrm{mg} / \mathrm{l}$ \\
\hline $\mathrm{BOD}_{3}\left(27^{\circ} \mathrm{C}\right)$ & $62 \mathrm{mg} / \mathrm{l}$ \\
\hline COD & 320 \\
\hline$\frac{B O D_{3}}{C O D}$ ratio & \\
\hline TKN & 11.3 \\
\hline TS & 6021 \\
\hline SS & 895 \\
\hline DS & $5126 \mathrm{mg} / \mathrm{l}$ \\
\hline E-coli & $3.6 \times 10^{5} / 100 \mathrm{ml}$ \\
\hline
\end{tabular}

Table-10: COD - removal after Alum Treatment

\begin{tabular}{|l|l|l|l|}
\hline $\begin{array}{l}\text { Alum } \\
\text { dosing mg/l }\end{array}$ & $\mathbf{p H}$ & COD mg/l & \% removal \\
\hline 100 & 7.44 & 275 & 14.06 \\
\hline 150 & 7.33 & 240 & 25.00 \\
\hline 175 & 7.25 & 180 & 43.75 \\
\hline 200 & 7.09 & 115 & 64.06 \\
\hline
\end{tabular}

Table-11: COD - removal after Lime Treatment

\begin{tabular}{|l|l|l|l|}
\hline $\begin{array}{l}\text { Lime } \\
\text { dosing mg/l }\end{array}$ & $\mathbf{p H}$ & COD mg/l & \% removal \\
\hline 100 & 7.61 & 305 & 4.68 \\
\hline 150 & 7.69 & 292 & 8.75 \\
\hline 175 & 7.76 & 287 & 10.31 \\
\hline 200 & 7.88 & 282 & 11.88 \\
\hline
\end{tabular}

Table-12: COD - removal after Lime - Alum Treatment

\begin{tabular}{|c|c|c|c|c|}
\hline $\begin{array}{l}\text { Lime } \\
\text { dosing } \\
\text { mg/l }\end{array}$ & $\begin{array}{l}\text { Alum - } \\
\text { dosing } \\
\text { mg/l }\end{array}$ & pH & $\begin{array}{l}\text { COD } \\
\mathrm{mg} / \mathrm{l}\end{array}$ & $\begin{array}{l}\% \\
\text { removal }\end{array}$ \\
\hline 100 & 100 & 7.55 & 245 & 23.43 \\
\hline 150 & 150 & 7.57 & 220 & 31.25 \\
\hline 175 & 175 & 7.68 & 160 & 50.00 \\
\hline 200 & 200 & 7.74 & 93 & 70.94 \\
\hline
\end{tabular}

Table-13: COD-Removal after Lime - Alum with Biological Treatment

\begin{tabular}{|l|l|l|l|l|}
\hline $\begin{array}{l}\text { Lime } \\
\text { dosing } \\
\text { mg/l }\end{array}$ & $\begin{array}{l}\text { Alum - } \\
\text { dosing } \\
\text { mg/l }\end{array}$ & pH & $\begin{array}{l}\text { COD } \\
\text { mg/l }\end{array}$ & $\begin{array}{l}\text { \%emoval } \\
\text { remol }\end{array}$ \\
\hline 100 & 100 & 7.53 & 227 & 29.06 \\
\hline 150 & 150 & 7.55 & 196 & 38.75 \\
\hline 175 & 175 & 7.61 & 132 & 58.75 \\
\hline 200 & 200 & 7.69 & 51 & 84.06 \\
\hline
\end{tabular}

Last data is for the sample generated in laboratory (with rainfall condition) given below :

Table-14: Characteristics for raw leachates

\begin{tabular}{|c|c|}
\hline Parameters & Value \\
\hline $\mathrm{pH}$ & $7.31 \mathrm{mg} / \mathrm{l}$ \\
\hline $\mathrm{BOD}_{3}\left(27^{0} \mathrm{C}\right)$ & $\mathrm{mg} / \mathrm{l}$ \\
\hline $\mathrm{COD}$ & 218 \\
\hline$\frac{\mathrm{BOD}_{3}}{\mathrm{COD}}$ ratio & \\
\hline TKN & $\mathrm{mg} / \mathrm{l}$ \\
\hline TS & 5238 \\
\hline SS & $998 \mathrm{mg} / \mathrm{l}$ \\
\hline DS & $4240 \mathrm{mg} / \mathrm{l}$ \\
\hline E-coli & $3.6 \times 10^{5} / 100 \mathrm{ml}$ \\
\hline
\end{tabular}

\section{DISCUSSION ON EXPERIMENTAL RESULTS}

The percentage wise components of solid waste of Okha landfill varied widely from one to one and 'Food Wastes' only itself contributes highest $25.506 \%$ of the total wastes of the landfill. The components 'Demolition wastes' \& 'Special waste' are $17.594 \%$ and $16.80 \%$ respectively and stood the next to food wastes accordingly. The minimum \% claimed by 'Leather' and 'Rubber' components that are ' $0.613 \%$ ' and ' $0.644 \%$ ' respectively. But the Ferrous materials, glass, tin, paper, plastic are not found in large quantity may be the reason for the segregation of all these items from the source of generation initially. 
The colour of leachate for all samples are almost same and looks blackish. Study reveals that BOD, COD, TS, TSS and TDS concentrations are always high in leachate without rainfall condition. But rainfall dilutes the concentrations of all above contaminations and transferred to soil structure of landfill. Only the $\mathrm{pH}$ values are increases after rainfall in the leachate. Pertaining to the microbiological characteristics of leachate it may be noted that in all types of leachate, coliform organism counts are above $3.6 \times 10^{5} / 100 \mathrm{ml}$. This may have a serious implication when leachate finds it's way into a nearby water body or spot sources. In analysis on the performances of leachate treatment, the anaerobic biological treatment shows best result in respect of all types of physico-chemical treatments and only in physico-chemical treatment, better performance shows by alum than lime.

\section{CONCLUSION}

The characteristics of solid wastes generated in the different places of Delhi are very typical and it's compositions varied widely by weight from each other. From study it reveals that total decomposable wastes are approximately $58.464 \%$ where as non-decomposable i.e inorganic wastes are $41.536 \%$ that posses a great threat to Okhla landfill for shortage of land area in future. The production of inorganic wastes should be minimize at the source of generation and is better to reuse in any constructional project. The contamination of leachate after rainfall becomes very low except coliform count. This lighted a clear indication of pollution of landfill due to non available of barricade that needs protection for the existing vital environment soil, air, water and biota.

\section{REFERENCES}

[1]. Chain , E.S and Dewalle, F.B., "Sanitary Landfill Leachate and their Treatments" Journal of Environmental Engineering Divn. ASCE (1974), 102(EE-2) : 215-239.

[2]. Ho. S. Boyle, W.C, and Ham. R.K, "Chemical Treatment of Leachates from Sanitary Landfill", Journal of Water Pollution Control Federation (2001) 46(7) : 17761791

[3]. Rao, K. J, "Assessment and Management of Environmental Pollution in some Developed Countries", Journal of IAEM .Vol-24 (1977) 68-77.

[4]. Smith, P. G, “ Treatment of Leachate from Landfills ”, The Public Health Engineers, Vol-9, No. 1-4, Jan'1981

[5]. Thorton. R.J and Blake. F.C., "Leachate Treatment by Coagulation and Precipitation, Journal of Environmental Div . ASCE(1998) , 99(EE-4): 535-544

[6]. Omar Al-Jarrah, Hani Abu- Qdais, " Municipal solid waste landfill sitting using intelligent system", "ElsevierWaste Management, 26(2006), pp 299-306 